\title{
THE LEARNING OF PRODUCING SHORT-STORY TEXT USING PROBLEM-BASED METHODS FOR HIGH SCHOOL STUDENTS
}

\author{
Aurelia Sakti Yani ${ }^{1}$ \\ IKIP Siliwangi, Jl Terusan Sudirman, Cimahi, Jawa Barat Indonesia \\ aureliasaktiyani13@gmail.com
}

\begin{abstract}
This research was conducted using descriptive methods. Where researchers will describe the work of students to get more detailed results. Before the research was conducted, the pretest was first held to find out more about where the students' ability was about producing short text. After that learning is done by applying the problem-based method, and ends with the posttest as a method of proving that effectiveness. The results showed that after learning to produce short text using this problem method, the ability of students to produce short stories increased. This is evidenced by the achievement of learning objectives and improved student learning outcomes. The increase can be seen from the results of the comparison of the average pretest is 56,5 and the average postest score is 69.2 . Thus the posttest average is higher than the average pretest.
\end{abstract}

Keywords: Producing Short Text, Problem Based Learning

\begin{abstract}
Abstrak
Penelitian ini dilaksanakan dengan menggunakan metode deskriptif. Dimana peneliti akan mendskripsikan hasil kerja siswa untuk mendapatkan hasil yang lebih terperinci. Sebelum dilakukan penlitian, lebih dulu diadakan pretest untuk mengetahui sejauh mana kemampuan siswa tentang memproduksi teks cerpen. Setelah itu dilakukan tahap pembelajaran dengan menerapkan metode berbasis masalah, dan diakhiri dengan posttest sebagai pembuktian keefektifan metode tersebut. Hasil penelitian menunjukan bahwa setelah dilakukan pembelajaran memproduksi teks cerpen dengan menggunakan metode berbasisis masalah ini ternyata kemampuan siswa dalam memproduksi teks cerpen meningkat. Hal ini terbukti dengan tercapainya tujuan pembelajaran dan peningkatan hasil evaluasi siswa yang lebih baik. Peningkatan tersebut dapat dilihat dari hasil perbandingan rata-rata pretest yaitu 56,5 dan nilai rata-rata postest yaitu 69,2. Dengan demikian rata-rata posttest lebih tinggi dari rata-rata pretest.
\end{abstract}

Kata Kunci: Memproduksi Teks Cerpen, Pembelajaran Berbasis Masalah

How to Cite: Yani, SA (2020). The Learning Of Producing Short-Story Text Using ProblemBased Methods For High School Students. JEE, 3 (1), 13-18. 


\section{INTRODUCTION}

Indonesian learning has a scope and purpose that fosters the ability to express thoughts and feelings by using the good and right language. The scope of Indonesian language learning in the 2013 curriculum includes a component of literary abilities that includes aspects of editing, producing, identifying, evaluating, interpreting abstracting and converting. Writing is very important in producing written work. By producing an article, the writer can develop his paper in the 2013 curriculum there are basic competencies to produce, therefore the writer will put more emphasis on producing activities.

The skill of producing short stories is not something that can be taught through mere description or explanation. Students will not gain production skills just by sitting, listening to the teacher's explanation and taking notes on the teacher's explanation. Short story producing skills can be improved by continuing to produce short stories so that they will affect the results and achievements of students in producing short stories. The results and achievements can be improved if the students' behavioral attitude changes both knowledge, skills and psychomotor aspects. Not a few students who experience obstacles in developing short story producing skills. These obstacles are the lack of imagination of students, the diction used in producing short stories is less varied, difficulty in determining themes, and less able to develop ideas. The role of the teacher is very dominant in the learning process. Students are less active and often this method creates boredom for students in learning to produce short stories so that the work produced by students is less maximal. The short story he made was not interesting because the language used was monotonous, and the development of ideas or ideas was less varied.

Producing skills are not solely owned by the group of people who are gifted to produce, but with real practice, those skills can be possessed by anyone. Students are expected to be able to improve their ability to put ideas or experiences into a literary work, which is a short story easily and can produce good work. The teacher as the delivery of material to students must be able to deliver the material to be discussed with the right method or media and attract the teacher as an inspiration, motivator, and facilitator for their students.

Therefore, the teacher plays an important role in this problem. The role of the teacher here is to make students feel comfortable and interested in what is taught in producing short stories and be able to motivate students to be able to improve the ability to produce students, especially in writing short stories. Here the author will discuss producing skills, especially producing short text. The author will try to solve the problem above by using learning methods that are in accordance with the 2013 curriculum, which is a problem-based learning method. A problem-based learning method is a learning approach where students are faced with authentic (real) problems so that they are expected to be able to organize their own knowledge, develop high-level skills and inquiry.

\section{Understanding Short Stories}

According to (Kosasih 2013, hlm. 111), the text that we have read is commonly referred to as a short story (short story), which is a story that according to its form is short. For the short length of the story is relative. However, in general, short stories are stories that have been read for about ten minutes or half an hour. The number of words is around 500-5000 words

Short story structures are generally shaped by (1) the introduction of stories, (2) ascending towards conflict, (3) the peak of conflict, and (5) resolution. There are parts that mention the 
terms abstarism, orientation, complications, evaluation, resolution, and code. As for the understanding of these structures are as follows:

\section{Abstraction}

Abstraction or synopsis is part of a story that illustrates the whole story. Such abstract existence in short stories is optional, may or may not appear. Moreover, stories in short stories tend to be direct to important events, not long-winded, directly focused on the main conflict (Kosasih, 2013, hlm. 113).

\section{Orientation}

Orientation or decapitation of the story, both with regard to characterizations and the seeds of the problems they experience (Kosasih, 2013, hlm. 114).

\section{Complications}

Complications or the peak of the conflict, which is part of a short story that tells the peak of the problem experienced by the main character. The problem is of course not desired by the character. This section is also the most tense and the reader curiosity about the way the character in solving the problem can be answered. In this section also, the character faces and resolves the problem and then certain consequences or consequences arise that defuse the previous problem (Kosasih, 2013. hlm 114).

\section{Evaluation}

Is a part that states the author's comments on the peak event that has been told. The comment in question can be stated directly by the author or represented by certain figures.

In this section the plot or conflict of the story is somewhat relaxed, but the reader still waits for the implications or further conflict as the end of the story (Kosasih, 2013: 114).

\section{Resolution}

Is the final stage of completion of the whole series of stories. The difference with complications, in this section there are only small problems remaining and need to be resolved as a "clean up" step (Kosasih, 2013, hlm. 114).

\section{Koda}

Is a final comment on the entire contents of the story, maybe also filled with conclusions about things experienced by the main character later (Kosasih, 2013, hlm. 114)

\section{Problem Based Learning}

According to (Wena, 2011, hlm. 52) affirming that "problem-solving learning becomes very important to be taught". Based learning is a learning process that uses a systematic approach to solving problems encountered in real life. (Amir, 2009, hlm. 21) in Wena argues that problem-based learning is also interpreted as "a learning model that challenges students to learn to learn, work together with groups to find solutions to real problems". The learning process is directed so that students are able to solve problems systematically. Student development not only occurs in cognitive aspects, but also affective and psychomotor aspects through an internal appreciation of the problems faced (Sanjaya, 2009, hlm. 214). Thus, problem-based learning is a learning model that departs from students' understanding of a problem, finding alternative solutions to problems. Then choosing the right solution to be used in solving problems.

And according to (Amir, 2009, hlm. 22) in Wena states that problem-based learning has the following characteristics: 
1. The problem is used in the beginning of learning.

2. The problem used is a real problem.

3. The problem at hand requires review from various perspectives.

4. Interesting problems for students to gain new learning experiences

5. Prioritizing independent learning.

6. Make use of varied sources of knowledge.

7. Be collaborative, communicative, and cooperative

The steps based on problem based learning (Kemdikbud, 2013, hlm. 113) are as follows:

1. Educators explain the learning objectives and logistics facilities needed. Educators motivate students to engage in real or selected problem solving activities

2. Educators help students define and organize learning tasks related to problems that have been oriented in the previous stage

3. Educators encourage students to gather appropriate information and carry out experiments to get the clarity needed to solve problems

4. Educators help students to share assignments and plan or prepare appropriate work as a result of problem solving in the form of reports, videos, or models.

5. Educators help students to reflect or evaluate the problem solving process that is done.

\section{METHOD}

The method is a way that must be taken to achieve the goals set (Arikunto, 2006, hlm. 160). The use of appropriate methods can help solve problems in research. So the method is an organized way that is systematically arranged for the goals that have been determined previously.

The research method used is descriptive method. The reason for using descriptive methods is because to describe or explain a phenomenon or nature factually and accurately about the facts investigated in learning to produce short stories using problem-based learning models.

Descriptive research is research conducted to describe or explain systematically, factually and accurately about the facts and nature of certain populations (Sanjaya, 2013, hlm. 59). Meanwhile, according to Nazir (2011 hlm. 54), descriptive method is a method in examining the status of a group of people, an object, a set of conditions, a system of thought, or a class of events at the present time. Meanwhile, according to (Arikunto, 2006, hlm. 108), the descriptive method is to collect as much data as possible about the factors that are supporting the quality of teaching and learning, then analyze these factors to look for their role in achievement

\section{RESULTS AND DISCUSSION}

\section{Results}

On the results of the pretest, the total value of the experimental class total value is 245 . While the value of the total control class is 205 . The results of the posttest number of experimental class values are a total of 260 values. can improve students' short story text producing skills.

Table 1. Student Grades before Using the Problem Based Method

\begin{tabular}{ccc}
\hline PAM & Eksperiments & Control \\
\hline High & 95 & 80 \\
Medium & 80 & 70 \\
Low & 70 & 55 \\
\hline
\end{tabular}


Table 2. Student Grades after Using Problem Based Methods

\begin{tabular}{ccc}
\hline PAM & Eksperiments & Control \\
\hline High & 100 & 80 \\
Medium & 85 & 75 \\
Low & 75 & 65 \\
\hline amount & 260 & 220 \\
\hline
\end{tabular}

\section{DISCUSSION}

Based on tables 1 and 2 above there are some conclusions related to the acquisition of student learning outcomes, namely: the results of the pretest, the number of experimental class scores the highest value 95 , medium value 80 , and the lowest value 70 total number 245 . While the value of the control class scores high 80 , medium value 70 and lowest value 55 total value 205.

The results of the posttest number of experimental class scores the highest value 100, medium value 85 , and the lowest value 75 total value 260 . While the control class value is as high as 80 , medium value 75 and the lowest value 65 total value 220 .

The final results of learning research produce short story text using problem-based learning, described as follows:

Pretest Value:

Average Value $=\underline{\text { Amount of Values }}$

$$
\begin{aligned}
& =\frac{1469}{26} \\
& =56,5
\end{aligned}
$$

Post-Value:

Average Value $=\underline{\text { Amount of Values }}$

$$
\begin{aligned}
& =\frac{1800}{26} \\
& =69,2
\end{aligned}
$$

Based on the information above there is a comparison of the pretest and posttest values, namely the average pretest is 56.5 and the average posttest value is 69.2. Thus the average post-test is higher than the average pretest.

\section{CONCLUSION}

Based on the research results obtained by the author, the authors conclude as follows:

1. Students are able to produce short story texts well when learning using problem-based learning methods. This can be seen from the scores obtained by the author through the results of the initial test scores (pretest) and the results of the final test scores (posttest). This increase in value can be seen from the calculation of the comparison between the two results, namely the initial test (pretest) and the results of the final test score (posttest).

2. Effective problem-based learning methods are used at the high school level, this effectiveness lies in the freedom of students when producing short stories in creating and 
expressing their own ideas, and using the language they use according to the events or realities of daily life.

3. Based on the results of the analysis showed an increase in the ability to produce short text, because it can be seen from the difference in the acquisition of the average pretest value of 1469 or 56.5 and the post-test value increased to 1800 or 69.2 . From the acquisition of these values prove that there is an increase in students' ability to produce short stories after the application of problem-based learning models into the learning process of producing short stories.

\section{ACKNOWLEDGMENTS}

The author thanks Dr. H. Rochmat Tri Sudrajat, M.Pd as supervisor I and Diena San Faujiya M.Pd. as the supervisor II and to the Principal of the Middle School who has given permission to carry out this research.

\section{REFERENCES}

Arikunto, Suharsimi. (2006). Penelitian Tindakan Kelas. Jakarta: PT Bumi Aksara.

Depdikbud. (2008). Kamus Besar Bahasa Indonesia (KBBI).

Kementrian Pendidikan dan Kebudayaan. (2013). Bahasa Indonesia Ekspresi Diri dan

Akademik. Jakarta: Kementrian pendidikan dan Kebudayaan.

Kementrian Pendidikan dan Kebudayaan. (2013). Konseptual Pendekatan Scientific.

Kementrian Pendidikan dan Kebudayaan.

Kosasih, Engkos. (2013). Jenis-jenis Teks: Analisis Fungsi, Struktur, dan Kaidah serta

Langkah Penulisannya. Jakarta: Erlangga.

Sanjaya,Wina. (2013). Penelitian Pendidikan . Jakarta: Kencana Prenada Media Group.

Nazir, Moh. (2011). Metode Penelitian. Bogor : Ghalia Indonesia.

Wena, Made. (2011). Strategi Pembelajaran Inovatif Kontemporer: suatu tinjauan konseptual operasional. Jakarta: Bumi Aksara. 